\title{
PENGEMBANGAN BUKU AJAR BAHASA INDONESIA BERMUATAN NILAI-NILAI KARAKTER MENGGUNAKAN MODEL PEMBELAJARAN BERBASIS MASALAH
}

\author{
Iva Mursida \\ Madrasah Aliyah Negeri Babat Kab Lamongan \\ Telp/Fax. (0322) 451471 \\ E-mail ivamursyida@yahoo.co.id
}

\begin{abstract}
Abstrak: Tujuan dalam penelitian pengembangan ini adalah untuk mengetahui proses pengembangan bahan ajar menggunakan model pengembangan four-D dan untuk mengetahui kualitas pengembangan bahan ajar Bahasa Indonesia bermuatan nilai-nilai karakter dengan menggunakan model pembelajaran berbasis masalah. Kualitas pengembangan terdiri atas kevalidan, keefektifan, dan kepraktisan.Dalam penelitian dan pengembangan ini dihasilkan produk berupa bahan ajar Bahasa Indonesia bermuatan nilai-nilai karakter dengan menggunakan model pembelajaran berbasis masalah. Proses pengembangan bahan ajar digunakan model pengembangan four-D yaitu memiliki 4 ( empat) tahap proses, yakni 1. Pendefinisian, 2. Perancangan, 3.Pengembangan, 4.Penyebaran. Data kualitas pengembangan berupa data kevalidan, keefektifan, dan kepraktisan.Hasil penelitian ini berisi tentang proses pengembangan dan data kualitas pengembangan. Pada tingkat kevalidan, memperoleh total skor90,5 \%. Pada tingkat kepraktisan, memperoleh hasil sangat baik berdasarkan keterlaksanaan RPP 88\%, respon siswa 87\%, respon guru 88\%.Pada tingkat keefektifan, aktivitas siswa memperoleh skor $85 \%$ dan aktivitas guru memperoleh skor $80 \%$.
\end{abstract}

Kata kunci: Buku Ajar, Bahasa Indonesia, nilai-nilai karakter, pembelajaran berbasis masalah.

\begin{abstract}
The purpose of this research is to know the process development of teaching materials using a four- D model of development and to determine the quality of the development of teaching materials Indonesian containing character values using problem-based learning model. Quality development consists of the validity, effectivity, and practicality.. In this research and development resulting product in the form of teaching materials Indonesian containing character values using problem-based learning model. The process of development of teaching materials used four- D model of development that has 4 ( four ) steps of the process, namely 1. Define, 2. Design, 3. Develop, 4. Dessiminite. Data quality development in the form of data validity, effectivity, and practicality. The results of this study contains development process and data quality development. At the level of validity, obtaining a total score of $90.5 \%$. At the level of practicality, obtain excellent results by keterlaksanaan RPP 88\%, the student response $87 \%, 88 \%$.In response rate teacher effectiveness, student activities earn a score of $85 \%$ and activities for teachers to get a score of $80 \%$.
\end{abstract}

Keywords : Textbook, Indonesian Language, character values, problem-based learning . 


\section{PENDAHULUAN}

Pembelajaran bahasa Indonesia dalam Kurikulum 2013 tidak hanya difungsikan sebagai alat komunikasi, tetapi juga sarana berpikir. Pada pembelajaran Bahasa Indonesia dari SD sampai dengan SMA menekankan pada pembelajaran berbasis teks. Teks dimaknai sebagai satuan bahasa yang mengungkapkan makna secara kontekstual. Teks adalah ungkapan pikiran manusia yang lengkap yang di dalamnya ada situasi dan konteksnya (Mahsun, 2013).

Salah satu buku yang dapat dimanfaatkan guru dalam dunia pendidikan adalah buku teks, dengan buku teks program pembelajaran bisa dilaksanakan secara lebih teratur, sebab guru sebagai pelaksana pendidikan akan memperoleh pedoman materi yang jelas. Buku ajar merupakan salah satu alat penunjang keberhasilan pembelajaran. Hasil penelitian Depdiknas (2004: 27) menyatakan bahwa pengajaran yang sukar dan bukan merupakan mata pelajaran yang menyenangkan. Salah satu penyebabnya adalah buku ajar kurang menarik bagi siswa.

Pengembangan buku ajar dilakukan untuk memberikan sumber masukan sebagai pengalaman yang dirancang untuk meningkatkan belajar bahasa (Tomlinson, 1998:2). Buku ajar dapat dikembangkan dan berfungsi sebagai pemancing interaksi pembelajaran bahasa adalah buku teks.

Kurikulum 2013 juga menitikberatkan pada pendidikan karakter. Seperti yang kita ketahui, pendidikan karakter juga bisa diberikan melalui ketersediaan buku-buku pelajaran di sekolah. Fakta yang terjadi di lapangan, buku-buku pelajaran yang tersedia kurang menunjukkan penggunaan nilai-nilai karakter.
Strategi pembelajaran berbasis masalah merupakan salah satu strategi pembelajaran inovatif yang berbasis inkuiri. Strategi pembelajaran berbasis masalah dikenal sebagai pembelajaran dengan menyajikan kepada siswa situasi masalah yang autentik dan bermakna, yang kemudian akan merangsang siswa untuk berpikir lebih kritis dan situasi masalah yang disajikan juga akan memudahkan siswa dalam berpendapat dan menggungkapkan bagaimana cara penyelesaiannya.

Menurut Boud dan Felleti dalam Muslimin (2000:7), pembelajaran berdasarkan masalah (problem based learning) adalah suatu pendekatan untuk membelajarkan siswa untuk mengembangkan keterampilan berfikir dan keterampilan memecahkan masalah, belajar peranan orang dewasa yang otentik serta menjadi pelajar mandiri. Pembelajaran berbasis masalah tidak dirancang untuk membantu guru memberikan informasi yang sebanyakbanyaknya kepada siswa, tetapi pembelajaran berbasis masalah dikembangkan untuk membantu siswa mengembangkan kemampuan berpikir, pemecahan masalah dan keterampilan intelektual, belajar berbagai peran orang dewasa melalui pelibatan mereka dalam pengalaman nyata dan menjadi pembelajaran yang mandiri. Berdasarkan paparan di atas, perlu adanya penelitian yang bertujuan untuk (1) mendeskripsikan proses pengembangan buku ajar Bahasa Indonesia bermuatan nilai-nila karakter dengan menggunakan model pembelajaran berbasis masalah, (2) mendeskripsikan kualitas buku ajar Bahasa Indonesia bermuatan nilai-nilai karakter menggunakan model pembelajaran berbasis masalah. 


\section{METODE PENELITIAN.}

Penelitian ini menggunakan model penelitian pengembangan (research and development), karena penelitian ini akan menghasilkan sebuah produk yang kemudian dapat dikembangkan dalam proses pembelajaran di kelas. Model pengembangan buku ajar yang dikemukakan oleh Thiagarajan, Samuel dan Semmel yang biasa disebut Four DModel (Model 4-D) terdiri atas (1) pendefinisian (define), meliputi analisis awal, analsis siswa, analisis konsep, analisis tugas, dan perumusan tujuan pembelajaran; (2) perancangan (design) mengikuti penyusunan buku ajar, pemilihan media, pemilihan format, dan desain awal; (3) pengembangan (develop), meliputi validasi ahli dan uji coba; dan (4) penyebaran (disseminate), meliputi duplikasi, sosialisasi, dan refleksi.

Data dalam penelitian ini meliputi 1) data proses pengembangan buku ajar Bahasa Indonesia dengan menggunakan model pembelajaran berbasis masalah berupa informasi proses pengembangan buku ajar melalui tahap pendefinisian, perancangan serta pengembangan dan 2) data kualitas buku ajar Bahasa Indonesia dengan menggunakan model pembelajaran berbasis masalah untuk peserta didik kelas X SMA/MA meliputi data kevalidan, kepraktisan dan keefektifan buku ajar .

Penganalisisan data pada penelitian ini dengan menggunakan analisis deskriptif kualitatif dan teknik analisis deskriptif kuantitatif. Data dideskripsikan berdasarkan kualitas data dan berdasarkan hasil perhitungan angka.

\section{HASIL PENELITIAN \\ Proses Pengembangan Buku Ajar Tahap Pendefinisian}

Proses pengembangan dalam penelitian ini dimulai dengan tahapan pendefinisian, yang mulai dilaksanakan pada tanggal 2Mei 2016 (analisis awal, analisis siswa, analisis tugas, konsep dan tujuan pembelajaran).

\section{Tahap Perancangan}

Pada tahap perancangan, peneliti merancang desain yang menarik terkait bahan ajar mengunakan model pembelajaran berbasis masalah.Hal itu dimaksudkan agar buku ajar yang menjadi objek pengembangan ini menarik untuk dipahami para guru dan siswa. Peneliti mulai menyusun materi buku ajar dengan mengikuti tahapan-tahapan pembelajaran berbasis masalah, yaitu orientasi siswa pada masalah, mengorganisasikan siswa untuk belajar, membimbing penyelidikan individu maupun kelompok, mengembangkan dan menyajikan hasil karya, dan menganalisis dan mengevaluasi proses pemecahan masalah.Tahapan ini dilakukan pada akhir Juli 2016.

\section{Tahap Pengembangan}

Tahapan pengembangan dilaksanakan Juli - Agustus 2016.Kegiatan revisi I ini dilakukan pada 12 Juli 2016. Penilaian, komentar dan saran validator ahli materi dan validator teman sejawat digunakan untuk merevisi draf I buku ajar Bahasa Indonesia. Revisi ini, pertama melakukan perbaikan atas komentar dan saran perbaikan dari validator 1 Ahli materi, validator 2 ahli materi, validator 1 teman sejawat, dan validator 2 teman sejawat.

Jadi secara umum, penilaian dan komentar dari validator ahli materi dan validator teman sejawat menunjukkan bahwa buku ajar Bahasa Indonesia dengan menggunakan metode pembelajaran berbasis masalah baik dan layak digunakan dengan revisi/menambah hal yang perlu. 
Berbagai masukan dan saran dari tim validator ahli materi dan teman sejawat telah selesai direvisi. Buku ajar yang telah dinilai dan direvisi disebut draf II. Draf II yang telah direvisi selanjutnya diuji coba.

Uji coba I merupakan uji coba terbatas yang dilaksanakan 19 Juli 2016 pada siswa kelas $\mathrm{X}$ yang berjumlah 8 siswa yang diambil dari kelas X Bahasa. Uji coba tersebut bertujuan mengidentifikasi kekurangan-kekurangan yang terjadi pada produk buku ajar Bahasa Indonesia dengan model pembelajaran pembelajaran berbasis masalah

Pada kegiatan uji coba terbatas, guru mengajar kepada siswa dengan menggunakan buku ajar yang dikembangkan. Secara keseluruhan, siswa dalam uji coba terbatas memberikan respon positif karena siswa dapat memahami materi yang disajikan, siswa merasa senang dengan adanya buku ajar tersebut dan siswa termotivasi untuk belajar.

Berdasarkan komentar dan saran dari siswa pada uji coba terbatas terdapat beberapa komentar yang menurut pertimbangan dapat dilakukan perbaikan dan perubahan. Perbaikan tersebut adalah memperbaiki kata-kata kurang tepat yang terdapat pada buku siswa yang dikembangkan. Perbaikan tersebut dengan mengedit penulisan kata-kata dan kalimat awal sampai akhir materi supaya tidak terjadi kesalahan lagi dan membuat buku ajar yang dikembangkan baik dan memudahkan siswa dalam memahami materi yang ada dalam buku ajar.

Uji coba luas dilaksanakan pada 1 dan 3 Agustus 2016 pada siswa kelas X.IPA-1 berjumlah 30 siswa. Uji coba luas dilaksanakan selama 2 kali pertemuan dengan mempelajari $1 \mathrm{KD}$, yaitu KD. 3.1 Memahami struktur dan kaidah teks laporan hasil observasi, baik melalui lisan maupun tulisan dan KD. 4.1 Menginterpretasi makna teks laporan hasil observasi, baik secara lisan maupun tulisan. Penilaian penguasaan materi memahami dan meninterpretasi teks laporan hasil observasi dilaksanakan pada pertama dan hari kedua.

Uji coba luas dilaksanakan pada 1 Agustus 2016 jam pertama dan jam kedua. Sesuai dengan jadwal, kegiatan pembelajaran dimulai pukul 07.00-08.30 WIB.Pada akhir pembelajaran, siswa diberi angket respon siswa untuk memberikan penilaian terhadap buku ajar yang dikembangkan.Pada kegiatan uji coba luas tersebut, semua siswa memberikan respon positif terhadap buku ajar yang dikembangkan.Selain itu, siswa juga memberikan saran tentang penulisan kata-kata dalam buku teks yang menurut mereka ada tulisan tanda baca kata yang kurang tepat, dan tentang warna-warna dalam buku ajar yang menurut mereka bagus dan gambar yang menarik.

Pada pertemuan kedua, dilaksanakan pada tanggal 3 Agustus 2016 jam ketiga dan keempat. Sesuai dengan jadwal, kegiatan pembelajaran dimulai pukul 08.30-10.00 WIB. Pada akhir pembelajaran, siswa diberi angket respon siswa untuk memberikan penilaian terhadap buku ajar yang dikembangkan. Pada kegiatan uji coba luas tersebut, semua siswa memberikan respon positif terhadap buku ajar yang dikembangkan. Selain itu, siswa juga memberikan saran tentang penulisan kata-kata dalam buku teks yang menurut mereka ada tulisan tanda baca kata yang kurang tepat, dan tentang warna-warna dalam buku ajar yang menurut mereka bagus dan gambar yang menarik.

Secara keseluruhan, respon siswa dalam uji coba luas memberikan respon positif karena siswa dapat memahami materi yang disajikan, siswa merasa 
senang dengan adanya buku ajar tersebut dan siswa termotivasi untuk belajar.

\section{Tahap Penyebaran}

Pada tahap ini peneliti melakukan musyawarah dengan guru Bahasa Indonesia di MAN Babat. Setelah kegiatan ini dilaksanakan, peneliti melanjutkan merevisi agar buku ajar sesuai dengan yang diharapkan.

\section{Kualitas Buku Ajar}

Kualitas bahan ajar Bahasa Indonesia bermuatan nilai-nilai karakter menggunakan model pembelajaran berbasis masalah untuk peserta didik SMA/MA kelas $\mathrm{X}$ didasarkan atas kevalidan, keefektifan dan kepraktisan. Kevalidan didasarkan atas hasil penilaian buku ajar dari validator. Kefektifan didasarkan atas respons guru dan siswa. Kepraktisan didasarkan atas aktivitas siswa dan deskripsi aktivitas siswa selama pembelajaran.

Kualitas buku ajar dapat dilihat pada tabel berikut ini

\section{Rekapitulasi Hasil Kualitas Buku Ajar}

\begin{tabular}{|c|c|c|c|c|c|c|}
\hline \multirow{9}{*}{$\begin{array}{l}\text { Kualitas } \\
\text { Buku Ajar }\end{array}$} & \multirow{4}{*}{ Kevalidan } & Validasi Ahli (V1) & $89 \%$ & Sangat baik & \multirow{4}{*}{$\begin{array}{l}\text { Sangat } \\
\text { Baik }\end{array}$} & \multirow{9}{*}{ Sangat Baik } \\
\hline & & Validasi Ahli (V2) & $89 \%$ & Sangat Baik & & \\
\hline & & $\begin{array}{l}\text { Validasi Teman } \\
\text { Sejawat (V1) }\end{array}$ & $90 \%$ & Sangat Baik & & \\
\hline & & $\begin{array}{l}\text { Validasi Teman } \\
\text { Sejawat (V2) }\end{array}$ & $91 \%$ & Sangat Baik & & \\
\hline & \multirow{3}{*}{ Kepraktisan } & Keterlaksanaan RPP & $88 \%$ & Sangat Baik & \multirow{3}{*}{$\begin{array}{l}\text { Sangat } \\
\text { Praktis }\end{array}$} & \\
\hline & & Respon Guru & $88 \%$ & $\begin{array}{l}\text { Sangat } \\
\text { Positif }\end{array}$ & & \\
\hline & & Respon Siswa & $87 \%$ & $\begin{array}{l}\text { Sangat } \\
\text { Positif }\end{array}$ & & \\
\hline & \multirow{2}{*}{ Keefektifan } & Aktivitas Guru & $85 \%$ & Sangat Baik & \multirow{2}{*}{$\begin{array}{l}\text { Sangat } \\
\text { Efektif }\end{array}$} & \\
\hline & & Aktivitas Siswa & $84,5 \%$ & Baik & & \\
\hline
\end{tabular}

Berdasarkan tabel 4.15 dapat disimpulkan bahwa kualitas buku Ajar dengan model pembelajaran berbasis masalah untuk siswa kelas X SMA/MA berkategori sangat baik. Hal ini ditunjukkan dengan kevalidan yang berkategori sangat baik, kepraktisan berkategori sangat praktis, dan keefektifan berkategori sangat efektif.

\section{PEMBAHASAN}

\section{Tujuan Menentukan Sasaran Pembelajaran dan Cakupan Materi}

Tujuan merupakan arah atau pedoman dalam melakukan suatu proses pembelajaran. Tujuan dirumuskan dengan kata kerja operasional yang menggambarkan perilaku yang terukur. Melalui rumusan tujuan, target yang akandicapai diketahui dengan jelas. Rumusan tujuan perlu diketahui oleh guru maupun siswa sehingga terjalin kerja sama untuk mencapai yang diharapkan.

Menurut Standar Proses pada Permendiknas Nomor 41 Tahun 2007, tujuan pembelajaran menggambarkan proses dan hasil belajar yang diharapkan dicapai oleh peserta didik sesuai dengan kompetensi dasar.

Pemilihan materi pada buku ajar memiliki relevansi dengan tujuan yang merupakan penjabaran KI dan KD sebagaimana tercantum dalam standar isi kurikulum 2013. Hal ini sejalan dengan yang dikemukakan oleh BNSP dalam Muslich (2010:291) tentang cakupan isi materi memenuhi kelayakan isi, 
penyajian, kebahasaan dan kegrafikan. Pada cakupan isi kesesuaian dengan kurikulum yang dijabarkan melalui indikator tujuan.

Indikator tujuan sangat penting diketahui untuk menentukan sasaran proses pembelajaran. Tidak semua buku atau materi ajar dilengkapi dengan mencantumkan tujuan. Peneliti menganggap tujuan merupakan hal yang penting dan harus ada.Melalui tujuan ini pengguna buku dapat melihat sasaran yang ingin dicapai pada setiap kompetensi.Kompetensi Dasar (KD) memahami teks laporan hasil observasi secara lisan dan tulisan berbeda halnya dengan KD membedakan teks laporan hasil observasi secara lisan dan tulisan, meskipun kedua KD tersebut.

\section{Pengetahuan dan Keterampilan Relevan dalam Jenjang dan Tingkat Kesulitan}

Berdasarkan kurikulum 2013, kompetensi inti aspek pengetahuan (KI3) dan aspek keterampilan (KI-4) tertuang dalam Peraturan Menteri (Permen) nomor 58 tahun 2014 tentang kurikulum SMA. Setiap kompetensi memiliki tujuan yang berbeda. Kompetensi memahami teks laporan hasil observasi memiliki indikator tujuan yang berbeda dengan kompetensi membedakan, mengklasifikasi, serta mengidentifikasi juga yang lainnya.Demikian pula pada tingkat kesulitan. Memahami lebih mudah dan merupakan tahap awal untuk sampai pada tahap membedakan. Demikian pula pada tahap membedakan lebih mudah dari mengklasifikasikan, sehingga tampak berjenjang dari yang mudah menuju ke yang tersulit.Kompetensi pertama merupakan tahap pertama yang dilalui siswa untuk mencapai tahap akhir yaitu kompetensi keempat dari kompetensi pengetahuan dan keterampilan.
Pemasangan

kompetensi pengetahuan (KI-3) dan keterampilan (KI-4) sesuai dengan permen 58 (2014;281). Pada pasangan kompetensi pengetahuan dan keterampilan tingkat kesulitan ini tampak, sehingga untuk memasangkan dua kompetensi antara pengetahuan dan keterampilan tahap dalam posisi memahami (3.1) dengan Menginterpretasi makna (4.1), membandingkan (3.2) dengan memproduksi (4.2), menganalisis (3.3) dengan menyunting (4.3), mengidentifikasi (3.4) dengan mengabstraksi (4.4), dan mengevaluasi (3.5) dengan mengonversi (4.5). Pemasangan kompetensi pengetahuan dan keterampilan diperkirakan memiliki tingkat kesulitan yang sama. Formasi seperti ini tidak menyulitkan siswa dalam memahami dan mempelajari buku ajar yang dikembangkan. Hal tersebut nampak pada data angket respon siswa pada materi teks laporan hasil observasi dengan kategori sangat positif, artinya siswa merespon sangat positif terhadap buku ajar yang dikembangkan serta mampu memahami dan mengikuti pembelajaran dengan menggunakan buku ajar yang dikembangkan dengan sangat baik.

Demikian pula berdasarkan hasil perhitungan ketuntasan belajar secara klasikal, diperoleh hasil yang sangat baik, artinya pasangan kompetensi tersebut mampu terlibat dalam pembelajaran dengan sangat baik sehingga hasil yang diperoleh pun sangat baik pula.

Tahapan Model Pembelajaran

Berbasis Masalah sangat Memungkinkan Siswa untuk Lebih Aktif dan Kreatif

Berdasarkan hasil penelitian wawancara dengan guru Bahasa Indonesia dan pengamataan penelitian pada tahap pendefinisian, siswa 
mempunyai akademik yang beragam. Dalam pembelajaran, peserta didik adalah subjek yang memiliki kemampuan untuk secara aktif mencari, mengolah, mengkonstruksi, dan menggunakan pengetahuan. Untuk itu pembelajaran harus berkenaan dengan kesempatan yang diberikan kepada peserta didik untuk mengkonstruksi pengetahuan dalam proses kognitifnya. Agar benarbenar memahami dan dapat menerapkan pengetahuan, peserta didik perlu didorong untuk bekerja memecahkan masalah, menemukan segala sesuatu untuk dirinya, dan berupaya keras mewujudkan ide- idenya.

Dalam mengimplementasikan model pembelajaran berbasis masalah, materi pembelajaran berbasis pada masalah yang fakta dalam kehidupan yang dapat dijelaskan dengan logika atau penalaran tertentu; bukan sebatas kirakira, khayalan, legenda, atau dongeng semata.

Dengan pembelajaran berbasis masalah akan terjadi pembelajaran bermakna. Peserta didik yang belajar memecahkan masalah maka mereka akan menerapkan pengetahuan yang dimilikinya atau berusaha mengetahui pengetahuan yang diperlukan. Peserta didik mengintegrasikan pengetahuan dan keterampilan secara simultan dan mengaplikasikannya dalam konteks yang relevan.

Penjelasan guru, respon siswa, dan interaksi edukatif guru-siswa terbebas dari prasangka yang serta-merta, pemikiran subjektif, atau penalaran yang menyimpang dari alur berpikir logis. Mendorong dan menginspirasi siswa berpikir secara kritis, analistis, dan tepat dalam mengidentifikasi, memahami, memecahkan masalah, dan mengaplikasikan materi pembelajaran. Berbasis pada konsep, teori, dan fakta empiris yang dapat dipertanggungjawabkan.

Pelaksanaan pembelajaran berbasis masalah merupakan pengorganisasian pengalaman belajar dengan urutan logis meliputi proses pembelajaran melalui: Mengorientasi masalah; Mengorganisasi siswa untuk belajar; Membimbing penyelidikan individu maupun kelompok; Mengembangkan dan menyajikan hasil kerja; dan Menganalisis dan mengevaluasi proses pemecahan masalah. Sedangkan Proses pembelajaran menyentuh tiga ranah, yaitu: sikap, pengetahuan, dan keterampilan. Hasil belajar melahirkan peserta didik yang produktif, kreatif, inovatif, dan afektif melalui penguatan sikap, keterampilan, dan pengetahuan yang terintegrasi.

Hasil akhirnya adalah peningkatan dan keseimbangan antara kemampuan untuk menjadi manusia yang baik dan manusia yang memiliki kecakapan dan pengetahuan untuk hidup secara layak dari peserta didik yang meliputi aspek kompetensi sikap, pengetahuan, dan keterampilan.

\section{Uji Coba sangat Berpengaruh pada Kualitas Produk yang dikembangkan}

Produk yang dikembangkan harus memiliki tingkat kevalidan, kepraktisan, serta keefektifan(Niaven dalam Shodiq, 2010:63). Untuk itu selain dilakukan validasi yang ditindaklanjuti dengan revisi, tahap selanjutnya uji coba produk.Revisi terus dilakukan untuk kesempurnaan produk buku ajar yang dikembangkan. Masukan dari validator ahli, teman sejawat, komentar guru dan siswa dijadikan masukan perbaikan produk. Selanjutnya menuju tahap uji coba produk.

Uji coba produk dilakukan dua tahap yaitu tahap pertama uji coba terbatas dan tahap kedua uji coba luas.Uji coba terbatas sangat penting untuk 
melihat kendala yang dihadapi siswa dalam memahami buku ajar, daya tarik buku ajar, serta kekurangannya. Buku ajar yang telah mengalami beberapa revisi dan dianggap sempurna belum tentu dapat mengalami siswa apabila belum diujikan melalui praktek langsung dalam pembelajaran. Melalui cara ini peneliti dapat melihat dan merasakan kekurangan yang masih ada. Kejelasan informasi dan, keluasan cakupan materi dalam buku ajar, kemudahan untuk diikuti oleh siswa.Melalui catatan reflektif, peneliti mencatat kendala yang dihadapi ketika melakukan pembelajaran dengan buku ajar yang dikembangkan.

Beberapa kendala yang dihadapi dalam pengembangan bahan ajar Bahasa Indonesia bermuatan nilai-nilai karakter menggunakan model pembelajaran berbasis masalah untuk kelas $\mathrm{X}$ SMA/MA.

Proses pengembangan bahan ajar Bahasa Indonesia bermuatan nilai-nilai karakter menggunakan model pembelajaran berbasis masalah untuk kelas X SMA/MA ini digunakan model pengembangan FourD yang terdiri atas Pendefinisian, Perancangan, Pengembangan, serta Penyebaran. Dalam setiap tahap proses pengembangan ditemukan banyak kendala. Pada tahap pendefinisian, telah dilakukan beberapa analisis, yakni analisis awal, analisis siswa, analisis konsep, analisis tujuan pembelajaran.

Kendala yang ditemukan pada tahap pendefinisian adalah saat peneliti mengamati pembelajaran dan menganalisis kebutuhan siswa.Terdapat sebagian besar siswa yang berpendapat evaluasinya terlalu banyak, sebagian lagi berpendapat cukup.Dengan pertimbangan tersebut maka peneliti mengurangi evaluasi yang ada dalam buku ajar tersebut.
Tahap kedua adalah Perancangan. Pada tahap Perancangan buku ajar, yang yang dilakukan peneliti adalah merancang materi ajar dan merancang desain ajar.Kendala yang ditemukan peneliti dalam tahap Perancangan adalah kurangnya pengetahuan peneliti tentang cara mendesain buku, akhirnya peneliti memilih satu orang pendesain yang ahli dalam desain grafis. Hal ini sangat membantu peneliti memecahkan permasalahan dalam tahap perancangan.

Tahap ketiga adalah Pengembangan.Kendala yang dihadapi peneliti ketika tahap pengembangan ini adalah ketika banyak revisi yang harus diselesaikan. Revisi tersebut meliputi aspek-aspek kelayakan isi/materi, kelayakan penyajian, kelayakan kebahasaan, serta kelayakan kegrafikaan.Berdasarkan hal tersebut peneliti banyak mencari tahu dari validator dan dosen pembimbing untuk mendapatkan pemecahan masalah demi kelengkapan buku ajar.

Tahap keempat adalah Penyebaran.Pada tahap penyebaran peneliti melakukan Musyawarah dengan Guru Bahasa Indonesia di MAN Babat.Setelah kegiatan ini dilaksanakan, peneliti harus melanjutkan merevisi agar buku ajar sesuai dengan yang diharapkan.

Untuk memotivasi siswa dalam belajar, peneliti menyediakan reward pada siswa yang aktif dalam belajar, yaitu siswa dengan mengemukanan pertanyaan yang relevan, menjawab dengan tepat, mempresentasikan hasil dengan benar, mengerjakan pekerjaan kelompok dan individu tepat waktu. Melalui cara ini siswa tampak lebih termotivasi. Hal ini tampak dengan penambahan jumlah siswa yang mau bertanya, menjawab atau mempresentasikan pekerjaannya tidak didominasi oleh orang yang sama atau ketua kelompok saja. Siswa yang aktif terlibatdalam pembelajaran rata-rata 
memperoleh nilai yang baik dan tuntas dalam belajar.

\section{Pemanfaatan Buku Ajar}

Buku Ajar merupakan buku pendamping yang digunakan dalam memperkaya khasanah pengetahuan siswa yang berisi keterbacaan, kebahasaan, dan teknik penulisan. Dalam kedudukannya dalam kurikulum 2013, buku ajar menjadi buku pendamping dengan buku yang deterbitkan oleh pemerintah. Buku yang diterbitkan pemerintah yaitu buku wajib yang digunakan pada sekolah-sekolah yang menggunakan kurikulum 2013. Kondisi kurikulum 2013 yang masih baru sehingga banyak guru yang belum paham dengan proses pembelajaraan yang harus dilakukan. Kekurangpahaman terhadap materi pembelajaran teks, model pembelajaran yang berdampak pada proses pembelajaran yang belum maksimal dan masih jauh dari harapan kurikulum.

Melalui buku ajar Bahasa Indonesia, guru dapat memperoleh model pembelajaran yang bervariasi .Indikator yang telah dicantumkan secara jelas pada buku menjadi arah pada pencapaian kompetensi yang harus dikuasai siswa. Melalui cara ini guru memperoleh informasi mengenai apa yang harus dilakukan sehingga indikator dapat tercapai. Tahapan model pembelajaran berbasis masalah membuat guru memberikan variasi pembelajaran yang dipakai di kelas. Untuk kemudahan dan kejelasan tahapan model pembelajaran berbasis masalah $\mathrm{k}$ diawali dengan mengorientasi masalah,mengorganisasi siswa untuk belajar, membimbing penyelidikan individu maupun kelompok, mengembangkan dan menyajikan hasil kerja,dan menganalisis dan mengevaluasi proses pemecahan masalah.
Melalui buku ajar Bahasa Indonesia, (1) dapat menyediakan buku ajar yang sesuai dengan tuntutan kurikulum dengan mempertimbangkan kebutuhan peseerta didik, yakni buku ajar yang sesuai dengan karakteristik dan setting atau lingkungan sosial peserta didik, (2) membantu peserta didik dalam memperoleh alternatif bahan ajar di samping buku-buku teks yang terkadang sulit diperoleh, (3) memudahkan guru dalam melaksanakan pembelajaran, (4) menambah khasanah pengetahuan dan pengalaman guru dalam menulis bahan ajar, (5) membangun komunikasi pembelajaran yang efektif antara guru dengan peserta didik karena peserta didik akan merasa lebih percaya kepada gurunya.

Dengan demikian, buku ajar memiliki kedudukan yang sangat penting. Buku ajar merupakan salah satu bagian dari sumber belajar yang berisi seperangkat materi penunjang yang dapat digunakan guru dan siswa dalam proses pembelajaraan. Buku ajar yang sesuai akan mendukung terwujudnya tujuan yang diharapkan. Oleh karena itu dalam proses pembelajaran diperlukan buku ajar yang benar-benar berkualitas.

\section{SIMPULAN}

Proses pengembangan buku ajar dilakukan dengan mengadaptasi model pengembangan 4-D yang meliputi tahap pendefinisian (define), tahap perancangan (desain), serta tahap pengembangan (develop). Pada tahap pendefinisian dilakukan 1) analisis awal . Pada tahap ini dilakukan analisis kurikulum serta analisis permasalahan yang terjadi di lapangan.Berdasarkan hasil analisis ditemukan berbagai kendala yang berkaitan dengan buku sebagai sumber belajar yang isinya belum maksimal, 2) analisis siswa, dilakukan dengan menganalisis kondisi siswa berdasarkan 
sikap, minat, movivasi, serta kemampuan akademik.Analisis ini berguna untuk mengetahui kemampuan awal siswa. 3) analisis konsep dilakukan dengan menganalisis kompetensi inti dan kompetensi dasar pada materi teks laporan hasil observasi 4) Perumusan tujuan, analisis tujuan dilakukan untuk merumuskan indikator hasil belajar yang diirumuskan menjadi tujuan pembelajaran. Selanjutnya dari tujuan tersebut dijadikan dasar untuk menentukan cakupan buku ajar yang dikembangkan.

Pada tahap perancangan dilakukan dengan membuat desain awal buku ajar.Selanjutnya dikembangkan menjadi draf I. Pada tahap pengembangan buku ajar draf I, selanjutnya divalidasi oleh ahli materi dan teman sejawat.Hasil penilaian dan saran validator ditindaklanjuti dengan merevisi produk. Setelah melalui revisi 1, buku ajar menjadi draf II selanjutnya dilakukan uji coba(terbatas). Setelah melalui uji coba 1 buku ajar direvisi tahap 2. Selanjutnya tahap uji coba luas selanjtnya direvisi tahap 3 menjadi produk akhir atau draf 4 .

Kualitas buku ajar yang dikembangkan meliputi kevalidan yang diperoleh angka sebesar 89\%. Dengan demikian buku ajar yang dikembangkan sangat layak digunakan.

Kepraktisan buku ajar yang dikembangkan diukur berdasarkan hasil pengamatan terhadap aspek keterlaksanaan RPP. Pada aspek ini diperoleh angka sebesar $88 \%$ dengan kategori sangat baik.Respon guru dan siswa terhadap buku ajar yang dikembangkan sangat positif.Respon guru sebesar $88 \%$, sedangkan respon siswa sebesar $87 \%$.
Keefektifan buku ajar yang dikembangkan diukur berdasarkan pengamatan aktivitas guru dalam pembelajaran berkategori baik dengan presentase aktivitas guru mencapai $85 \%$, sedangkan aktivitas siswa mencapai $84,5 \%$ dengan kategori baik, artinya buku ajar yang dikembangkan mampu mengantarkan siswa dalam mencapai ketuntasan belajar dengan baik.

\section{DAFTAR RUJUKAN}

Abidin, 2012. Pembelajaran bahasa berbasis pendidikan karakter, Bandung: Refika Aditama

Borg and Gall (1983) Educational Research, An Introduction. New York and London Longman,Inc

Departemen Pendidikan Nasional, Permendikbud Nomor 02 Tahun 2008 tentang Buku, Jakarta: Depdiknas, 2008

Depdiknas,2006. Pedoman Buku Pelajaran: Penjelasan Penulisan Buku Pelajaran

Mahsun,2013. Teks dalam Pembelajaran Bahasa Indonesia:Rajawali Pers

Muslich,Masnur(2010). Text Book Writing: Dasar-dasar Pemahaman dan Pemakaian Buku Teks, Yogyakarta: Ar-Ruzz Media

Muslimin, 2000. Pembelajaran Kooperatif: Unesa University Press, Surabaya.

Sugiyono. 2008. Metode Penelitian Kuantitatif Kualitatif dab R\&D. Bandung : Alfabeta

Suryaman,dkk,2006. Panduan pengembangan Materi

Pembelajaran. Solo: Depdiknas

Tarigan, Henry G. 2008. Menulis Sebagai Suatu Keterampilan Berbahasa. Bandung Angkasa. 